\title{
Crystal Structure of 8-Hydroxyquinoline-2-Carboxylic Acid Copper(II) Complex
}

\author{
Mitsunobu Nakamura, ${ }^{\dagger}$ Chitoshi Kitamura, Hitomi Ueyama, Kazushige Yamana, \\ and Akio YoNEDA \\ Department of Materials Science and Chemistry, Graduate School of Engineering, University of Hyogo, \\ 2167 Shosha, Himeji, Hyogo 671-2201, Japan
}

\begin{abstract}
A copper(II) complex with 8-hydroxyquinoline-2-carboxylic acid was synthesized and its crystal structure was determined by X-ray crystallography. 8-Hydroxyquinoline-2-carboxylic acid acted as a dibasic tridentate ligand to form a neutral mononuclear complex with a distorted square-pyramidal geometry with two water molecules.
\end{abstract}

(Received June 10, 2005; Accepted July 20, 2005; Published on web August 5, 2005)

Recently copper(II) complexes with an aromatic nitrogen base have attracted interest as nucleoside analogues for mimicking of nucleobase pairing ${ }^{1}$ or sensing of nucleobases. ${ }^{2} \quad$ Such nucleoside analogues may be utilized for creating antigene/antisense molecules, or for detecting therapeutic agents. We also synthesized some mononuclear copper(II) complexes with a tridentate ligand, 8-substitutedquinoline-2caroxylic acid, and investigated their specificity and binding affinity to nucleobases. ${ }^{3}$ This paper describes the synthesis and crystal structure of an 8-hydroxyquinoline-2-carboxylic acid (HQC) copper(II) complex, $\left[\mathrm{Cu}(\mathrm{HQC})\left(\mathrm{H}_{2} \mathrm{O}\right)_{2}\right]$.

The ligand HQC was synthesized from 8-hydroxyquinoline-2carbaldehyde, which was derived from 8-hydroxyquinaldine with $\mathrm{AgO}_{2}$, by oxidation using $\mathrm{SeO}_{2}$. The copper(II) complex $\left[\mathrm{Cu}(\mathrm{HQC})\left(\mathrm{H}_{2} \mathrm{O}\right)_{2}\right]$ was prepared by adding each of $\mathrm{Cu}\left(\mathrm{ClO}_{4}\right)_{2}$ and $\mathrm{NaOH}$ in aqueous solution at room temperature to $\mathrm{HQC}$ in ethanol. The precipitate was collected and dried over reduced pressure. Slow evaporation from a saturated aqueous solution of $\left[\mathrm{Cu}(\mathrm{HQC})\left(\mathrm{H}_{2} \mathrm{O}\right)_{2}\right]$ at room temperature gave dark-yellow needles, which are suitable for X-ray crystallography. The chemical structure of $\left[\mathrm{Cu}(\mathrm{HQC})\left(\mathrm{H}_{2} \mathrm{O}\right)_{2}\right]$ is shown in Fig. 1. The data were collected using a Rigaku/MSC Mercury CCD diffractometer at $223 \mathrm{~K}$. The liner absorption coefficient $(\mu)$ for Mo $K_{\alpha}$ radiation was $22.4 \mathrm{~cm}^{-1}$. A numeral absorption correction was applied, which resulted in transmission factors ranging from 0.78 to 0.95 . The data were corrected for Lorentz and polarization effects. A structure determination was carried out using the program SIR92. ${ }^{4}$ All of the non-hydrogen atoms were refined anisotoropically. The positions of the hydrogen atoms were determined from a difference Fourier map and were

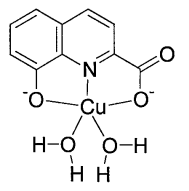

Fig. 1 Chemical structure of $\left[\mathrm{Cu}(\mathrm{HQC})\left(\mathrm{H}_{2} \mathrm{O}\right)_{2}\right]$.

$\dagger$ To whom correspondence should be addressed.

E-mail: mitunobu@eng.u-hyogo.ac.jp refined isotropically. All calculations were performed using the teXsan program package. ${ }^{5}$ Crystal and experimental data are listed in Table 1. The structure of the complex is shown in Fig. 2. The final positional parameters for all non-hydrogen atoms are given in Table 2, and selected bond lengths and bond angles are summarized in Table 3 .

The crystal structure of $\left[\mathrm{Cu}(\mathrm{HQC})\left(\mathrm{H}_{2} \mathrm{O}\right)_{2}\right]$ consists of mononuclear units in which each copper atom is coordinated by

Table 1 Crystal and experimental data

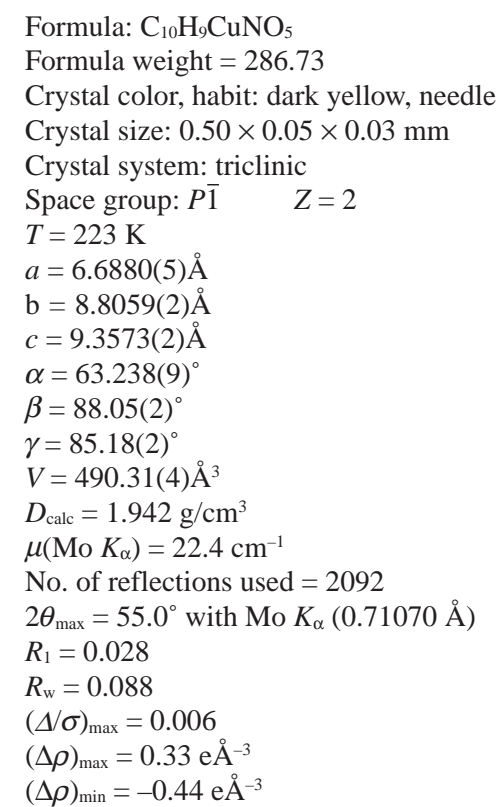

Measurement: Rigaku/MSC Mercury CCD

Program system: teXsan

Structure determination: direct methods (SIR92)

Refinement: full-matrix least-squares

CCDC 258750 contains the supplementary crystallographic data for this paper. These data can be obtained free of charge from The Cambridge Crystallographic Data Center via www.ccdc.cam.ac.uk/data_request/cif. 


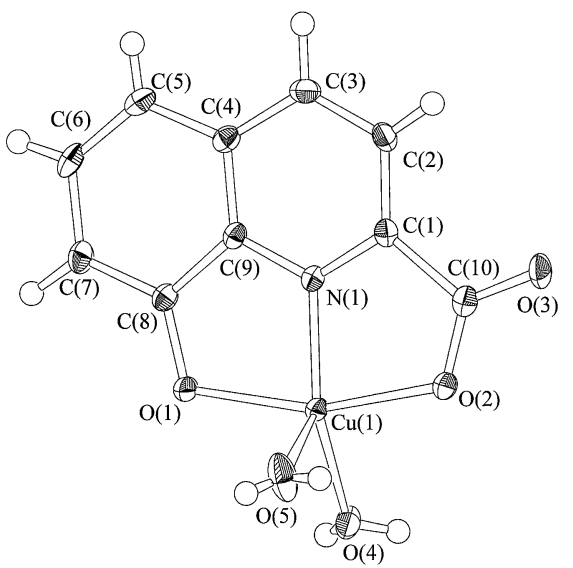

Fig. 2 ORTEP drawing of $\left[\mathrm{Cu}(\mathrm{HQC})\left(\mathrm{H}_{2} \mathrm{O}\right)_{2}\right]$ with atom labeling. The thermal ellipsoids are drawn at the $50 \%$ probability level. The spheres of the hydrogen atoms are drawn in an arbitrary scale.

Table 2 Atomic coordinates and equivalent isotropic thermal parameters $\left(B_{\mathrm{eq}}\right)$

\begin{tabular}{cccll}
\hline Atom & $x$ & $y$ & \multicolumn{1}{c}{$z$} & $B_{\mathrm{eq}}\left(\AA^{2}\right)$ \\
\hline $\mathrm{Cu}(1)$ & $0.70269(3)$ & $0.25801(3)$ & $0.32601(2)$ & $1.269(7)$ \\
$\mathrm{O}(1)$ & $0.7055(2)$ & $0.1164(2)$ & $0.5685(2)$ & $1.40(3)$ \\
$\mathrm{O}(2)$ & $0.7140(2)$ & $0.4564(2)$ & $0.1070(2)$ & $1.69(3)$ \\
$\mathrm{O}(3)$ & $0.7383(2)$ & $0.7378(2)$ & $-0.0161(2)$ & $1.76(3)$ \\
$\mathrm{O}(4)$ & $0.5381(3)$ & $0.1263(2)$ & $0.2609(2)$ & $1.71(3)$ \\
$\mathrm{O}(5)$ & $0.9920(3)$ & $0.1478(3)$ & $0.2841(2)$ & $2.53(3)$ \\
$\mathrm{N}(1)$ & $0.7381(2)$ & $0.4353(2)$ & $0.3824(2)$ & $1.05(3)$ \\
$\mathrm{C}(1)$ & $0.7471(3)$ & $0.5931(2)$ & $0.2700(2)$ & $1.15(3)$ \\
$\mathrm{C}(2)$ & $0.7645(3)$ & $0.7256(2)$ & $0.3114(2)$ & $1.40(3)$ \\
$\mathrm{C}(3)$ & $0.7731(3)$ & $0.6870(2)$ & $0.4711(2)$ & $1.50(3)$ \\
$\mathrm{C}(4)$ & $0.7613(3)$ & $0.5172(2)$ & $0.5933(2)$ & $1.26(3)$ \\
$\mathrm{C}(5)$ & $0.7667(3)$ & $0.4579(3)$ & $0.7617(2)$ & $1.55(4)$ \\
$\mathrm{C}(6)$ & $0.7541(3)$ & $0.2878(3)$ & $0.8599(2)$ & $1.63(4)$ \\
$\mathrm{C}(7)$ & $0.7335(3)$ & $0.1646(3)$ & $0.8042(2)$ & $1.50(3)$ \\
$\mathrm{C}(8)$ & $0.7261(3)$ & $0.2166(2)$ & $0.6409(2)$ & $1.18(3)$ \\
$\mathrm{C}(9)$ & $0.7426(2)$ & $0.3926(2)$ & $0.5397(2)$ & $1.04(3)$ \\
$\mathrm{C}(10)$ & $0.7327(3)$ & $0.5995(2)$ & $0.1047(2)$ & $1.36(3)$ \\
\hline
\end{tabular}

$B_{\mathrm{eq}}=(8 / 3) \pi^{2}\left(U_{11}\left(a a^{*}\right)^{2}+U_{22}\left(b b^{*}\right)^{2}+U_{33}\left(c c^{*}\right)^{2}+2 U_{12}\left(a a^{*} b b^{*}\right) \cos \gamma+\right.$ $\left.2 U_{13}\left(a a^{*} c c^{*}\right) \cos \beta+2 U_{23}\left(b b^{*} c c^{*}\right) \cos \alpha\right)$.

two $\mathrm{O}$ atoms and one $\mathrm{N}$ atom of the HQC ligand and two $\mathrm{O}$ atoms of two water molecules to form a distorted squarepyramidal $(4+1)$ geometry. An oxygen atom, $\mathrm{O}(5)$, in one of water molecule is located at the apical position $\left[\mathrm{O}(5)-\mathrm{Cu}(1)-\mathrm{N}(1)=111.21(7)^{\circ}\right.$ and $\mathrm{O}(4)-\mathrm{Cu}(1)-\mathrm{N}(1)=$ $\left.152.67(7)^{\circ}\right]$. HQC is a tridentate ligand and essentially planar. Three of the square-planar coordination sites are occupied by $\mathrm{O}(1), \mathrm{O}(2)$, and $\mathrm{N}(1)$ of HQC, and the fourth site of the basal plane is occupied by $\mathrm{O}(4)$ of another water molecule. The distance of $\mathrm{Cu}(1)-\mathrm{O}(5)$ is $2.195(2) \AA$, which is longer than those
Table 3 Selected bond lengths $(\AA)$ and bond angles $\left({ }^{\circ}\right)$

\begin{tabular}{cccccccc}
\hline atom & atom & distance & & atom & atom & distance \\
\hline $\mathrm{Cu}(1)$ & $\mathrm{O}(1)$ & $2.039(1)$ & & $\mathrm{Cu}(1)$ & $\mathrm{O}(2)$ & $2.011(1)$ \\
$\mathrm{Cu}(1)$ & $\mathrm{O}(4)$ & $1.956(2)$ & & $\mathrm{Cu}(1)$ & $\mathrm{O}(5)$ & $2.195(2)$ \\
$\mathrm{Cu}(1)$ & $\mathrm{N}(1)$ & $1.893(2)$ & & & & \\
\hline atom & atom & atom & angle & atom & atom & atom & angle \\
\hline $\mathrm{O}(1)$ & $\mathrm{Cu}(1)$ & $\mathrm{O}(2)$ & $161.71(6)$ & $\mathrm{O}(1)$ & $\mathrm{Cu}(1)$ & $\mathrm{O}(4)$ & $101.16(7)$ \\
$\mathrm{O}(1)$ & $\mathrm{Cu}(1)$ & $\mathrm{O}(5)$ & $96.01(7)$ & $\mathrm{O}(1)$ & $\mathrm{Cu}(1)$ & $\mathrm{N}(1)$ & $81.82(6)$ \\
$\mathrm{O}(2)$ & $\mathrm{Cu}(1)$ & $\mathrm{O}(4)$ & $95.30(7)$ & $\mathrm{O}(2)$ & $\mathrm{Cu}(1)$ & $\mathrm{O}(5)$ & $90.22(7)$ \\
$\mathrm{O}(2)$ & $\mathrm{Cu}(1)$ & $\mathrm{N}(1)$ & $79.90(6)$ & $\mathrm{O}(4)$ & $\mathrm{Cu}(1)$ & $\mathrm{O}(5)$ & $95.60(7)$ \\
$\mathrm{O}(4)$ & $\mathrm{Cu}(1)$ & $\mathrm{N}(1)$ & $152.67(7)$ & $\mathrm{O}(5)$ & $\mathrm{Cu}(1)$ & $\mathrm{N}(1)$ & $111.21(7)$ \\
\hline
\end{tabular}

between $\mathrm{Cu}(1)$ and other $\mathrm{O}$ atoms $[\mathrm{Cu}(1)-\mathrm{O}(1)=2.039(1) \AA$, $\mathrm{Cu}(1)-\mathrm{O}(2)=2.011(1) \AA$, and $\mathrm{Cu}(1)-\mathrm{O}(4)=1.956 \AA]$. The intra-ring bond angles $\mathrm{O}(1)-\mathrm{Cu}(1)-\mathrm{N}(1) \quad\left(81.82(6)^{\circ}\right)$ and $\mathrm{O}(2)-\mathrm{Cu}(1)-\mathrm{N}(1)\left(79.90(6)^{\circ}\right)$ are both much less than the interring bond angles $\mathrm{O}(1)-\mathrm{Cu}(1)-\mathrm{O}(4) \quad\left(101.16(7)^{\circ}\right)$ and $\mathrm{O}(2)-\mathrm{Cu}(1)-\mathrm{O}(4)\left(95.30(7)^{\circ}\right)$, respectively. The bond lengths and bond angles of the HQC ligand are in agreement with the standard values. The crystal structure is stabilized by a number of intermolecular hydrogen bonds in which the hydrogen atoms of the water link the carbonyl oxygen atom or the phenolic oxygen atom, showing a zigzag chain structure along the $a$-axis. Furthermore, it is interesting to note that the two ligand-planes across the inversion center are in parallel and separated by approximately $3.34 \AA$, indicating the presence of face-to-face $\pi$ $\pi$ stacking interactions.

We demonstrated that HQC acted as a dibasic tridentate ligand, and was coordinated to the copper(II) ion through the nitrogen atom, and two oxygen atoms of caroboxylate and hydroxylate in a distorted square-pyramid, which was completed by two water molecules. The base of the pyramid around the copper(II) ion was formed by a tridentate HQC anion and one water molecule. The second water molecule was located at the apical position.

\section{Acknowledgements}

We thank the Research Center for Molecular-scale Nanoscience, the Institute for Molecular Science, for assistance in obtaining X-ray data.

\section{References}

1. K. Tanaka and M. Shionoya, J. Org. Chem., 1999, 64, 5002.

2. F. Mancin and J. Chin, J. Am. Chem. Soc., 2002, 124, 10946.

3. Unpublished data.

4. A. Altomare, M. C. Burla, M. Camalli, M. Cascarano, C. Giacovazzo, A. Guagliardi, and G. Polidori, J. Appl. Cryst. 1994, 27, 435.

5. Crystal Structure Analysis Package, Molecular Structure Corporation, 1985 \& 1999. 